\title{
Effect of Social Media on Behaviour and Performance of State Civil Apparatus in The Government of Palangka Raya City
}

\author{
Stefani M.A.A. Koesanto ${ }^{1}$, Tresia Kristiana ${ }^{2}$, Nurul Robbi Sepang ${ }^{3}$, \\ Harapin Hafid ${ }^{4}$ \\ \{stefanimadeayu@ecampus.ut.ac.id ${ }^{1}$, tresiakristiana@yahoo.co.id ${ }^{2}$,n.robbi.s@uai.ac.id ${ }^{3}$, \\ harapin.hafid@uho.ac.id $\left.{ }^{4}\right\}$ \\ ${ }^{1}$ Indonesia Open University, Palangka Raya, Indonesia \\ ${ }^{2}$ Palangka Raya Chistian University, Palangka Raya, Indonesia \\ ${ }^{3} \mathrm{Al}$ Ahzar Indonesia University, Jakarta, Indonesia \\ ${ }^{4}$ Halu Oleo University, Kendari, Indonesia
}

\begin{abstract}
The rise of information technology and the audacity of freedom of speech are regulated in Law No. 19 of 2016 that provides legal framework for Electronic Information and Transaction (EIT), a guidepost for protecting rights, establishing disciplinary proceeding, maintaining order and guaranteeing legal certainty regarding the use of information and technology in Indonesia. The State Civil Apparatus (here in after SCA) are called upon to place loyalty to the existing Constitution and Laws; their conscience should decidedly require him to refrain from conducts that are either unlawful, unconstitutional or that bring about some great affront to human virtues. The present study sheds light on the use of social media and how it affects the behavior and performance of the SCA in the City Government of Palangka Raya. Our results show that, while the use of social media significantly affects the behavior, it does less significantly in the area of performance.
\end{abstract}

Keywords: Social Media, SCA Behavior, SCA Performance

\section{Introduction}

Indonesia is rapidly growing in terms of the use of information technology. Data from Indonesian Internet Service Providers Association (Asosiasi Penyelenggara Jasa Internet Indonesia, abbreviated to APJII) illustrates this rapid growing [1]; the number of internet users in Indonesia reached 143.260.000 people in 2017 [2]. This makes up 54\% of Indonesia's total population that amounted to 262 million people in 2017, with Kalimantan making up the internet population about $8 \%$. Social media penetration is also expanding within the same year; $87,13 \%$ of internet users constituted social media users.

The study suggests that future studies draw on additional independent variables to reevaluate the framework of the effect of social media on better work performance. In the present study, we model the relationship of the Internet that facilitates social media platforms and SCA behavior according to the ethical conducts regulated in Government Regulation of the Republic of Indonesia No. 21 of 1975 on Oath of Office; and SCA performance at the City Government of Palangka Raya. 
We look at the likes of Facebook and Instagram that are increasingly ingrained into and taking larger roles in government public relations than other platforms. According to a report from We Are Social and Hootsuite called Digital in 2017: Southeast Asia taken from Global Web Index, YouTube, Facebook and Instagram rank among social networking applications with the largest active users. Youtube pulled in $49 \%$ users, while both Facebook and Instagram sat at $38 \%$ [3]. It is, however, interesting to note that within Youtube landscape it is more about passive user experience, i.e., post-viewing activities, than active user experience, i.e., post-uploading activities. Though more users log into video consumption on Youtube, Instagram presents more content-creation activities. Instagram has made viewing and uploading activities more accessible to users to optimize their feed and has currently pushed into Instagram Story, Instagram Live and more recently IGTV, underscoring just about how many people are obsessively spending time on Instagram these days.

In a broad outline, the law highlights the content of some provisions that have been amended from Law No. 11 of 2008. In the present study, Law No. 19 of 2016 is the basis for the legal framework that specifically formulates the context of social media uses by SCA. We delve into Article 45, consisting of 5 provisions and 5 subarticles. The core of the article stipulates the legal consequence for an individual found guilty of intentionally distributing and/or transmitting and/or making accessible electronic information and/or documents that contain indecent, insulting, gambling and defamatory content, extortion and threat. Article 45A.1 in particular elaborates legal ramifications of any conduct with intent to convey and disseminate false and misleading information, while Article 4 A.2 regulates any individual convincingly proven to disseminate information, deliberately and without rights, intended to cause hatred or hostility.

There is a wealth of internal and external aspects in broad areas of behavior formation that vary among individuals. These may involve the arrangement of central nervous system, perception, motivation, emotion, learning process, environmental inputs and so on. Showing how perception is changing can lead to a circumstance where individuals can change. Perception draws on basic senses through which individuals associate with information to help them perceive and understand the world around them. Motivation reflects the urge that navigates behavior toward a goal. Emotion is the driving force behind motivation, and a profound emotional repercussion affects the extent to which one changes behavior.

Individuals cope with a wide array of mechanisms and factors of behavioral change. Theoretical constructs of behavioral change are similar to those of learning process [4] , i.e.:

1) Individuals are engaged with a stimulus of the external world through sensory experiences in the surrounding areas and react to it according to the requirements by accepting a certain stimulus or rejecting it. If a stimulus does not capture one's attention, the body does not react. If, on the other hand, a stimulus is strong enough to generate potential for action, the body will integrate the knowledge or experience and react quite appropriately.

2) When the acceptance of a stimulus takes place, the individual understands the stimulus and proceeds to the next stage.

3) Once the individual cultivates the stimulus, he evokes a sense of willingness to engage in certain behavior based on the perceived stimulus.

4) With environmental inputs, the stimulus drives the individual into taking action and, thus, elicit behavioral change.

Human behavior is complex and spans into a very broad range. Benyamin Bloom, an educational psychology expert, in Notoadmodjo breaks down the range of behavior into three domains [4] i.e., cognitive, affective and psychomotor domains, though the understanding of 
where the boundaries should exist remains unclear. The onset of new behavior emerges in a cognitive domain, particularly during adulthood, in a way that the subject is exposed to an external stimulus object, which allows him to know that object from which the subject generates new knowledge. This later elicits an inner response in a form of attitude to fit into the external object he now fully knows and understands. Through the stimulus, he undergoes further responses and captures full behavioral potential that assimilates the object and action. However, in reality, the stimulus is strong enough to create immediate potential for action; the subject can act on the information he receives and performs a behavioral response to receive the expected outcome. In other words, the basis for an action does not necessarily lie on knowledge nor attitude.

We draw on Benjamin Bloom's theory of behavioral change to delve into the expected change in behavior among the State Civil Apparatus in accordance with the Government Regulation of the Republic of Indonesia Number 21 of 1975 concerning the Oath of Office. The standard forms of behavior set out in the judicial oath include:

1. Faith in and obedience to Pancasila, the 1945 Constitution of the Republic of Indonesia, the State and the Goverment

2. Adherence to all existing laws and regulations and commitment to carrying out official duties with full dedication, awareness and responsibility

3. Upholding the honor of the State and the Government as well as maintaining the highest standard of integrity of the Civil Servants, and prioritizing the interest of the State above personal and group interest

4. Holding the duty of professional secrecy and confidentiality

5. Fulfilling duties with honesty, orderliness, meticulousness and passion for the sake of the State

Bernardin and Russel conceptualize the notion of performance in a workplace and state, "Performance is defined as the record of outcomes produced on a specified job function or activity during time period [5]." This definition measures individual's job performance strictly in terms of the outcomes or the sum produced at a certain period of time. Job performance is the result of work related to organizational goals, efficiency and other performance-effective practices [6]. In a broader sense, performance as the result or the level of overall success of an individual over a given time period in performing tasks as compared to a wide-ranging set of assessment, i.e., work performance standards, targets and criteria that have been predetermined and agreed upon [7]. Research suggests performance constitutes the level of achievement to ensure the implementation of certain tasks [8]. Individual performance is aligned with organizational performance, which involves analyzing the level of a company's achievement against its overall gamut of objectives and goals. Performance management ensures all individuals are aware of the performance levels and outcomes, and provides feedback to enhance areas where the performance is weak.

Performance, in nature, is concrete, and, thus, observable and measurable. Recognizing the types of performance, i.e., organizational performance, unit performance and employee performance, helps lead the key landscape of job performance into the whole construct of strategic objectives within an organization, which comprise organizational goals, unit goals and employee goals [9]. Employee work performance, as argues, measures the actual performance of an employee relative to performance expectation [10]. Performance expectation specifies the basis and the range of a set of achievement standards toward which individuals or groups channel their efforts. Performance expectation not only examines how well the job is executed but also bears the emphasis on peer relationships that impact employee engagement with an assigned task. 
The overall constructs of job performance among a rich body of prior studies track into a coherent whole; job performance serves a substantial role to represent objectives, benchmarks and milestones along professional trajectories among individuals and/or groups. We, therefore, place emphasis on individual efforts that translate into results to fit into how we evaluate SCA performance. Individual performance has a close linkage with individual potential and how it is best utilized to boost institutional or corporate performance. In this regard, cultivating individual performance navigates toward good organizational performance.

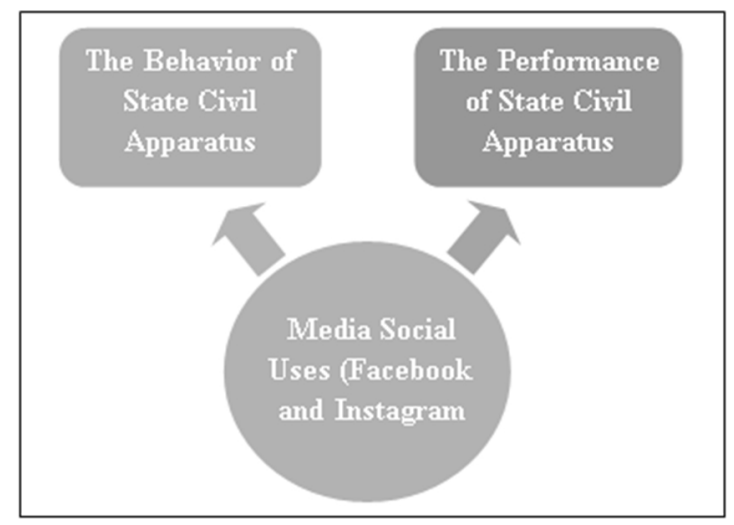

Fig 1. Research Analysis Model

\section{Research Method}

For our study needs, we collected primary data in a survey research where a questionnaire was distributed to the population of interest, i.e., the regional work units of the City Government of Palangka Raya. Likert scale was summed to gain a score for each respondent. Same items in the questionnaire were used in the interview and observation method serving as an approach to secondary data collection.

In data processing, a regression analysis was run in SPSS (Statistical Product and Service Solution) 20 for descriptive statistics. The relationship between independent variables (Xi ... $\mathrm{Xn})$ and dependent variable (Y) was modeled in a regression analysis and extended into a multiple regression analysis in the event of more-than-one independent variable. In a regression analysis, we extracted correlation to quantify the direction and strength of the linear association between social media; and the behavior and performance of the State Civil Apparatus in the City Government of Palangka Raya. Basic and classical assumptions were tested so as to assure best linear unbiased estimator (BLUE) was met for the statistical test. The result of basic assumption test provided insight and the necessary means to check for a normal distribution and linearity within the residual regression model. In classical assumption test, we kept track of multicollinearity, heteroscedasticity and autocorrelation.

Hypothesis testing was run in multiple linear regression analysis. Following the hypothesis test, we $\mathrm{f}$ it into ANOVA model and t test to identify simultaneous and partial contribution. In this phase, we looked at the direction of the relationship between the independent variable and dependent variable, which may be positive or negative, and predicted whether there was an increase or decrease in the dependent variable with each unit of increase in the independent variable. Multiple linear regression is formulated as follows: 


$$
\begin{aligned}
& Y 1=a+b \cdot X \\
& Y 2=a+b \cdot X
\end{aligned}
$$

Description:

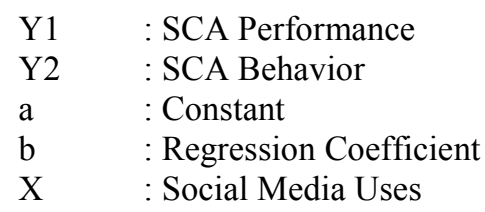

The adopted linear regression aspired to infer knowledge about the direct effect of social media on SCA performance and behavior. We drew SCA population throughout Palangka Raya City Government from bkpp.palangkaraya.go.id as of December 2015, which stood at 6438 individuals. Margin of Error (MoE) of 10\% was used, which resulted in a sample size of 100 SCA in the City Government of Palangka Raya across 33 offices or agencies. Dealing with three main variables, i.e., the use of social media, SCA behavior and SCA performance, we tapped into three dimensions that underlie the use of social media: 1) the frequency of social media use, 2) the intensity of social media use, and 3) the motivation for social media use. We observed how these dimensions affected SCA behavior through three aspects, i.e., cognitive aspect, affective aspect and cognitive aspect; and SCA performance across three aspects, i.e., initiative, dependence, maturity and contribution.

\section{Result and Discussion}

The regression results indicate that $95 \%$ of the respondents went to social media platforms for work-related information. The results of interview data show similar pattern; SCA stayed connected to social media to engage in work-related purposes and cope with task difficulties. Specifically, 90\% sought information to better understand the roles or tasks they were dealing with, and $80 \%$ used social media support to solve problems and complete work. $79 \%$ believed social media served as information-based tools and technologies to disseminate information and facilitate communication to the internal and external audiences within work context.

As far as the interview data are concerned, the results segmented Facebook users among the respondents with $20 \%$ claiming to have at least two personal accounts but sticking with one active account only. The bulk of the respondents signed up for social media on their own decision, not because of the influence of family or friends. They were engaged and active users claiming to have shared photos, uploaded videos, viewed them, liked them and commented on them. 34\% were avid social media users and admitted they could not go through a day without spending time on social media platforms. Only $8 \%$ went online anonymously, while the rest of $92 \%$ used personal accounts.

Regardless of how they made use of their online presence, $10 \%$ claimed social media activities are prone to wasting time as they spent endless hours on social platforms, while the remaining $90 \%$ did not. Similarly, $90 \%$ did not spend time on social media more than they did on duty. $62 \%$ were listed in friend groups on Facebook to increase the frequency and quality of work-related communication within internal scopes. $96 \%$ of the respondents took up the intensive use of social media as a conduit for knowledge development and sharing. The awareness and understanding of the Law of the Republic of Indonesia No. 19 of 2016 concerning Electronic Information and Transactions are not relatively new territory for the majority of respondents. Only 6 up to $10 \%$ of the respondents were found to have violated the 
ethical frameworks of the law on Facebook and Instagram, addressing cases such as hoax, moral offense, pornography, defamation, extortion, hate speech (involving political discourse), fraud, gambling, and content denoting racial, religious, ethnic slurs. About $3 \%$ were not aware of the rights, protection and the violation available under the law. The same percentage exhibited the subject of hate speech on the basis of national hostility. A small number of respondents were also found to have made derogatory remarks about the president or state officials and disseminated classified information about state secrets on their personal social platforms. $2 \%$ contested the priority of the country over personal or group interests. When it comes to the Presidential Regulation of the Republic of Indonesia No. 21 of 1975 and the Law of the Republic of Indonesia No. 19 of 2016, the data show a minor failure among the respondents to understand the legal consequences of going online; only $3 \%$ demonstrated deficient awareness of and erroneous views on the ethical codes of conduct on social media. As for the workplace behavior among the SCA, 3\% dealt with tardiness and struggled through core tasks owing to a lack of knowledge or skills.

We conducted interviews with two SCA (SCA 1 and SCA 2) to collect information about social media activities among the population from which we came up with interesting findings; while everyone is on social media, some of them forgo the distress of negotiating the limits on social media and opt not to engage with the whole fellow employees. SCA 1 contended that despite their awareness of the importance of the Oath of Office and the effort to restrict free expression on social media, content that celebrates racial, religious and ethnic slurs, particularly in a political context, remained common among several employees; there had been cases of pornographic content prior to the active legal practice of Law No. 19 of 2016. SCA 1 went on to acknowledge a glimpse of confusion between personal and professional use of social media. From a superordinate standpoint, SCA 2 pointed out that social media at workplace did not tremendously affect job performance of the SCA given that the public sectors within the regional work units of Palangka Raya City Government neither foster performance-based culture as yet (except Regional Income Agency) nor earn the benefit of a pay-for-performance scheme, which rewards SCA a form of performance-based compensation for their productivity. We drew data from the questionnaire and found $2 \%$ of the respondents felt undervalued and were not recognized for the contributions. In contrast to the Regional Income Agency, other agencies in public sectors do not capitalize much on social media for promotion, information-sharing activities and public communication as the performance-based renumeration scheme remains underutilized for the government service workers. Tables below provide general information about the regression data.

In the area of SCA performance, social media uses are not statistically significant, standing only at $22 \%$ and thus further corroborating the weak relationship between social media uses and public service performance.Statistical analysis is subsequently presented according to the dimensions of social media uses. In case of frequency, the majority of SCA were engaged users with a high level of social media activities on Facebook and Instagram on a daily basis. Only $29 \%$ engaged with the sites on a less frequent basis. From our interview results, we found several respondents to be so highly engaged with their social media activities every time a notification rings on their phone. However, the proportion of less active social media users is significantly higher. The finding corresponds to the interview data from SCA 2, who claimed to have logged on less often since his promotion to a leadership role.

In terms of intensity, social media uses, i.e., Facebook and Instagram, in relation to SCA professional purposes mainly concern with information-seeking activities, social connections, and organizational information-sharing schemes, which is profilerating at a formidable pace. The finding is in concert with the aforecited prior study, which highlights the potential of 
social media to locate promotional values and public relations. Taking into account organizational context, the motivation for social media uses are positively related to users' experience with job-related tasks such as government activity promotion and public communication. A somewhat surprising finding is that these tasks are made accessible on their personal accounts rather than organizational accounts. As a result, the behavior in terms of how they take on content creation and sharing on both professional account and personal account may get rather rumpled. This sets the stage for confusion and mismanaged expectation of running a professional account, which strictly aligns with professional areas of interest, and a personal account, which principally handles content that draws personal thoughts and, sometimes, emotional expressions.

We look at how social media affect the online behavior of the SCA and attribute all of the behavioral domains [4], i.e., cognitive, affective and psychomotor domain. Within cognitive domain, individuals embark on mental constructs and begin the knowledge and understanding of legal duties and moral responsibilities concerning making interaction and exchange of electronic information and documents. Within affective domain, individuals set up personality traits, exhibit legal obedience through a range of attitudes and deeds in compliance with the existing regulations imposed by the government, and consider avoiding defying a law because it is bad or unjust. However, the reality is not what it seems. Irrespective of sufficient awareness of the legal consequences defined in the Presidential Regulation of the Republic of Indonesia No. 21 of 1975 and Law N0. 19 of 2016, common law offenses remain. Both laws attempt ensure that the SCA adhere to social media rules and regulations, but a few remain ignorant to some of these social media violations. Our data indicate that $6-10 \%$ of the respondents were found to have committed innapropriate use of social media (Facebook and Instagram) that constitutes an ethical violation according to the laws.

Individual differences in behavioral domains are subject to how individuals differ in thinking and feeling, encouragement or references from others (particularly those who are close and trustworthy), surrounding resources and socio-cultural relevance. Within organizational culture in public sectors, SCA are called upon to nurture positive attitudes, and develop strong work ethics and moral compasses according to the instructions under the indicated regulatory standards. The ultimate guide to work integrity and ethical conduct makes it necessary for public-sector organizations to monitor how SCA approach social media practices and specify how to use them for personal uses or organizational objectives.

In the area of performance, social media can foster social capital and knowledge transfer for SCA, which ultimately can facilitate better job performance. However, this area is beset with a challenge; the government have yet to justify its decision to implement pay-forperformance systems throughout public sectors, and consequently government workers are not properly motivated. As a result, the levels of social media penetration in public administration to serve the principles of transparency, active participation and collaboration in public sector remain lower than those in organizations that benefit from pay-for-performance plans. Our data show that most respondents took high-level initiatives to advance their work, and only $3 \%$ were found to grapple with underperformance. Though social media does not have a direct impact on public communication in public sectors, it boosts individual performance upon job completion by facilitating them platforms where they can seek job-related information and share ideas.

In practice, engaging SCA to the expected levels of achievement is key to organizational goals within public sectors. Performance management helps achieve these organizational goals by incorporating a work setting that monitors the performance of an organizational unit and employee within each division and subdivision. Job performance through social media 
platforms can leverage on social capital indicated by network ties, and shared vision and trust. $79 \%$ of the respondents were found to use social media for public relations with key audiences to protect and promote organizational reputation.

Based on the interview results, the respondents were well aware of the values of social networking sites to exchange information in a cost-effective and easy manner and, at the same time, took great pride contributing to organization productivity and effectiveness. A number of leading government agencies in the City Government of Palangka Raya do not run official social media accounts for public outreach. However, citizens can still rely on the information, data and plans that state or local governments post on their official websites. These websites, though accessible, are not effective enough for optimal public outreach. It is, therefore, not so surprising that a number of SCA take the initiative to post professional content that supports their work-related activities and information on their personal social media accounts.

\section{Conclusion}

We have laid out a conceptual model in which social media uses affect the behavior and performance of State Civil Apparatus, with accompanying statistical analysis. The model is empirically tested by regression analysis, revealing that:

1. Social media uses significantly affect how SCA at the City Government of Palangka Raya behave while online.

2. The pace of change social media impose on the performance area of SCA remains sluggish, thus playing a less significant role in shaping the impact of social sharing platforms on SCA performance that those on SCA behavior.

3. Overall, this study points to further research efforts that can highlight social media patterns and the forces that come with them as well as SCA performance schemes throughout regional government agenci es at the City Government of Palangka Raya.

\section{References}

[1] Asosiasi Penyelenggara Jasa Internet Indonesia.: Infografis: Penetrasi dan Perilaku Pengguna Internet di Indonesia survey, 2017.

[2] Setiawan, Sakina Rakhma Diah.: Tahun 2017, Pengguna Internet di Indoensia Mencapai 143, 26 Juta Orang. $\quad$ Retrieved from https:/ekonomi.kompas.com/read/2018/02/19/161115126/tahun-2017-penggunainternet-di-indonesia-mencapai-14326-juta-orang/ on March 9, 2018.

[3] Databoks Katadata Indonesia. : Inilah Media Sosial dengan PenggunaAktif Terbesar di Indonesia. Retrieved from https://databoks.katadata.co.id/datapublish/2017/09/13/inilahmedia-sosial-dengan-pengguna-aktif-terbesar-di-indonesiaon March 9, 2018.

[4] Notoadmodjo, Soekidjo.: Ilmu Perilaku Kesehatan. Jakarta. Rineka Cipta, 2010.

[5] Ruky., Ahmad.: Sistem Manajemen Kinerja. Jakarta. Gramedia Pustaka Utama, 2002.

[6] Gibson, et al.: Organization: Behaviour Structure Processes. Eleventh Edition. New York. Mc Graw Hill, 2003.

[7] Rifai, Veithzal.: Performance Upraisal. Jakarta. PT Raja Grafindo Persada, 2005.

[8] Simanjuntak, Payaman J.: Manajemen dan Evaluasi Kerja. Jakarta. Lembaga Penerbit FEUI, 2005.

[9] Irawan, Handi.: 10 Prinsip Kepuasan Pelanggan. Jakarta. PT. Elex Media Komputindo, 2002.

[10] Dessler, Gary.: Manajemen SDM buku 1. Jakarta. Indeks, 2009. 
